\title{
Examination of the knowledge, attitude and
}

\section{behaviours of pregnant women on screening tests}

\section{made during pregnancy}

\author{
Dilek Kusaslan Avci ${ }^{*}$, Ercan Oner \\ Department of Family Medicine, Medical Faculty of Yuzuncu Yil University, V an, Turkey
}

\begin{abstract}
The importance of screening tests gradually increases in prenatal evaluation today and they find a larger usage area. The purpose of our study was to examine the knowledge, attitudes and behaviors of pregnant women about pregnancy screening tests.

This study included a total of 313 pregnant women followed up and treated in obstetrics polyclinic and service. The questionnaire form consisting of 57 questions was completed through face to face interviewing method in our study. Information on the sociodemographical characteristics, additional diseases, pregnancy characteristics, Rh incompatibility, gestational diabetes mellitus, double screening test, triple screening test and TORCH infections were recorded for the patients.

It was detected that 39.3\% ( $\mathrm{n}=123)$ didn't know about her own blood group and $65.8 \%$ didn't know ( $=206)$ about her husband's blood group. It was detected that $79.9 \%(\mathrm{n}=250)$ of the participants in our study heard about Rh incompatibility and $12.64 \%$ of these participants $(n=30)$ didn't have any information on whether they had $\mathrm{Rh}$ incompatibility in their own pregnancies or not. In our study, it was detected that $52.8 \%$ of the pregnant women thought that OGTT should be done. In our study, it was observed that the knowledge levels of the pregnant women on screening tests and their ratio of taking screening tests were not satisfactory. It was detected that some of the pregnant women had wrong information on screening tests. A standard training should be programmed to inform pregnant women on the screening tests made during pregnancy and this training should be managed in Family Health Centers and hospitals.
\end{abstract}

Key Words: Pregnancy, Screening Tests, Knowledge, Attitude

\section{Introduction}

The importance of screening tests gradually increases in prenatal evaluation today and they find a larger usage area. Screening tests are the tests used to determine the high risky group for a certain disease or anomaly among healthy individuals. So they have to be easily applicable, highly reliable and cost-efficient. The aim of the screening tests made during pregnancy is to detect fetuses with anomaly and the diseases as early as possible and to inform the family (1).

$\mathrm{Rh}$ incompatibility has great importance as it may cause hemolytic anemia, hydrops fetalis and hyperbilirubinemia related kernicterus. To protect children from these risks in case of $\mathrm{Rh}$ incompatibility, the mother should be given $\mathrm{Rh} D$ antiglobulin in the 28th week of pregnancy and in the first 72 hours after delivery $(1,2)$ in case of bleeding.
Toxoplasma gondii, Rubella, Cytomegalovirus and Herpes simplex are evaluated in TORCH screening. These factors may cause intrauterine infections occurring in a similar clinical presentation in the fetus in case of infection during pregnancy (3). There are different views still discussed on the necessity of TORCH screening during pregnancy. Based on the seropositivity ratio of the area, the required examinations for toxoplasma, cytomegalovirus, rubella and herpes simplex virus should be done when pregnancy is detected and the patient should be informed on this subject.

Other aneuploidies and triploidies such as Down Syndrome (trisomy 21), Patau Syndrome (trisomy 13), Edwards Syndrome (trisomy 18) and Turner syndrome can be detected with double and triple screening test. Down Syndrome is the most common chromosome anomaly seen in 1-2 out of 1000 live births. If Down Syndrome risk is

${ }^{*}$ Corresponding Author: Assist. Prof. Dr. Dilek Kusaslan Avci, Department of Family Medicine, Medical Faculty of Yuzuncu Yil University, Van, Turkey, 
$\geq 1: 250$, genetic consultation should be provided to the family and prenatal diagnosis should be made according to the family's decision $(4,5)$

Gestational diabetes mellitus (GDM) is observed in nearly $7 \%$ of the pregnancies. Pregnancies complicated with diabetes are risky pregnancies requiring both maternal and fetal close follow-up. When adequate glycemic control cannot be provided, gestational diabetes mellitus is a metabolic disorder which can cause morbidities and mortalities in a different spectrum from congenital malformations or in utero death in the infant to maternal hypoglycemia to ketoacidosis and increase in retinopathy and nephropathy. Oral glucose tolerance tests (OGTT) which are diagnosis and screening tests for GDM are generally made between the 24 and 28th weeks of pregnancy. Because the diabetogenic effects of pregnancy occur between these weeks and there is enough time to be able to treat the effects which may be seen in the mother or the infant (6). But in high risked pregnancies, it is suggested to make screening as soon as pregnancy is detected (7). To protect the mother and infant from these risks, pregnant women should be informed on gestational diabetes mellitus and early detection and treatment should be provided for the risky group (8).

The aim of our study was to examine the knowledge, attitude and behaviours of pregnant women on screening tests made during pregnancy (Rh incompatibility, TORCH infections screening, double screening test, triple screening test, GDM screening) and to inform pregnant women about these tests.

\section{Material and Method}

This study was made in Yuzuncu Yil University Faculty of Medicine Gynecology and Obstetrics Clinic between July 15 and September 15, 2016. Our study included a total of 313 pregnant women followed up and treated in obstetrics polyclinic and service. The questionnaire form consisting of 57 questions was completed through face to face interviewing method in our study. Information on the sociodemographical characteristics, additional diseases, pregnancy characteristics, $\mathrm{Rh}$ incompatibility, gestational diabetes mellitus, double screening test, triple screening test and TORCH infections were recorded for the patients.

While the definitive statistics for the constant variables covered in the study were stated as Mean, Standard Deviation, Minimum and Maximum values, they were stated as Number and
Percentage for Categorical variables. Chi-square test was made to determine the relation between the groups and the categorical variables. Statistical significance level was taken as $5 \%$ in the calculations and SPSS (ver.18) statistical package program was used for the calculations.

Ethical consideration: Ethical approval was obtained from Medical School, Yuzuncu Yil University Ethics Committee (REC/ REF: 111/12.08.2016). All participants gave written consent for this study. The study was conducted in accordance with the principles of the Declaration of Helsinki.

\section{Results}

It was detected that the average age of the participants was 26.86 \pm 5.761 (min:19,max:43), average marriage duration was $6.85 \pm 6.063$ (min:1,max:26) years and the average pregnancy week was $23.83 \pm 11.256$ (min:5, max:40). It was detected that $13.4 \% \quad(n=42)$ of the participants were illiterate, 94.2\% ( $\mathrm{n}=295)$ were housewife, $23 \%(\mathrm{n}=72)$ had an income lower than their expenses and $2.9 \% \quad(n=9)$ didn't have social security.

It was detected that $46.3 \%(n=145)$ considered screening tests necessary in pregnancy follow-ups, $15 \%(n=47)$ considered as unnecessary and $38.3 \%$ $(\mathrm{n}=120)$ didn't have any idea. Table 1 shows that the conditions associated with respondents' responses to the necessity of the screening tests.

It was detected that $39.3 \%(n=123)$ didn't know about her own blood group and $65.8 \%$ didn't know $(n=206)$ about her husband's blood group. While $73.8 \%$ of illiterate participants $(n=31)$ didn't know about their own blood group, this ratio was detected as $50.9 \%(\mathrm{n}=29)$ in literate participants, $50.6 \%$ in elementary school graduates $(n=40)$, $25.4 \%$ in secondary school graduates $(n=16)$, $12.2 \%$ in high school graduates $(n=5)$ and $6.5 \%$ $(n=2)$ in university graduates $(p=0.000)$. It was detected that $79.9 \%(n=250)$ of the participants in our study heard about $\mathrm{Rh}$ incompatibility and $12.64 \%$ of these participants $(n=30)$ didn't have any information on whether they had $\mathrm{Rh}$ incompatibility in their own pregnancies or not. Knowledge of the participants with $\mathrm{Rh}$ incompatibility on when to make Anti D immunoglobulin injection in case of $\mathrm{Rh}$ incompatibility was stated in Table 2. It was detected that $78 \%$ of the participants in our study heard about gestational diabetes mellitus, $44.3 \%$ knew why OGTT was made, $25 \%$ had OGTT and $25 \%$ will have OGTT. $52.86 \%$ of the participants 
Table 1. Examining the responses of participants to the necessity of screening tests (Chi-square test, $\mathrm{p}<0.05)$.

\begin{tabular}{lll}
\hline & $\%(\mathrm{n})$ & $\mathrm{p}$ \\
\hline $\begin{array}{l}\text { Distribution according to socio-economic status in those } \\
\text { who say that screening tests are necessary in pregnancy }\end{array}$ & & 0.008 \\
Income higher than their expenses & $49.1(53)$ & \\
Income equal to their expenses & $46.2(61)$ & \\
Income lower than their expenses & $42.3(30)$ & \\
Distribution according to education levels in those who & & \\
say that screening tests are necessary in pregnancy & & \\
Illiterate & $26.2(11)$ & \\
literate & $35.7(20)$ & \\
Primary school & $54.4(43)$ & \\
Middle School & $44.4(28)$ & \\
High school & $48.8(20)$ & \\
University & $74.2(23)$ & \\
\hline
\end{tabular}

Table 2. Knowledge of the participants with Rh incompatibility on when Anti D immunoglobulin injection would be made in Rh incompatibility (n:30)

\begin{tabular}{ccc}
\hline When is an injection made for Rh incompatibility? & $\mathrm{n}$ & $\%$ \\
\hline In the 28th week & 14 & $46.7 \%$ \\
After birth & 13 & $43.3 \%$ \\
In case of bleeding & 7 & $23.3 \%$ \\
I don't know & 7 & $23.3 \%$ \\
\hline
\end{tabular}

* $\mathrm{n} "$ is high since some participants select more than one option

$(\mathrm{n}=129)$ stated that OGTT was necessary, 25\% stated that it was not necessary $(\mathrm{n}=61)$ and $22.13 \%$ stated that she had no idea on the subject. The causes for not taking OGTT are stated in Table 3.

It was stated that $76 \%$ of the participants heard about double screening test. It was detected that $37.4 \%$ of the participants who stated that they heard about this test said that they didn't know why it was made, $55.9 \%(n=133)$ stated that this test should be done, $32.8 \%$ stated that $(n=78)$ it was not necessary and $11.3 \%$ didn't have any idea on this subject. The causes for not taking double screening test are stated in Table 3.

It was detected that $32.9 \%$ of the participants $(n=103)$ heard about triple screening test, $16.3 \%$ took triple screening test and $18.3 \%$ will take it. $59.6 \%$ of the participants who heard about this test $(n=62)$ stated that they didn't know why this test was made, $56.7 \%$ stated that they regarded this test necessary, 20.2\% ( $\mathrm{n}=21)$ didn't regard it necessary and $65.4 \%(n=68)$ didn't or won't take this test. The causes of pregnant women for not taking triple test were stated in Table 3.
It was detected that $28.4 \%$ of the participants $(n=89)$ heard about TORCH infections. $35.5 \%$ of the participants who stated that they heard about this test $(\mathrm{n}=31)$ stated that they had TORCH screening, 25\% stated that they didn't know whether these tests were made for them and $94.3 \%$ stated $(n=83)$ that pregnant women should have TORCH screening. The causes for not taking TORCH tests are stated in Table 3.

\section{Discussion}

Pregnancy controls to be made in regular intervals starting from the detection of pregnancy provide the opportunity to early recognize risks which may be encountered during pregnancy, to prevent or treat them without severe results (9).

Bleeding can occur any time during pregnancy. $\mathrm{ABO} / \mathrm{Rh}$ group should be demanded during the first antenatal control in all pregnant women and their husbands both for this reason or to detect $\mathrm{Rh}$ incompatibility (10). In the study by Canbaz et al on female health professionals, it was detected that $1.9 \%$ of the pregnant females didn't know 
about their own blood groups and 4.8\% didn't know about the blood groups of their husbands (11). In the study on the society by Ergün et al, it was detected that $21.6 \%$ of the pregnant females didn't know their blood groups and 29.2\% didn't know their husbands' blood groups (12). In our study, it was detected that $39.3 \%$ of the pregnant women didn't know about their own blood groups and $65.8 \%$ didn't know about their husbands' blood groups. The cause for the high ratios in our study was related to the low education level of the pregnant women in our study.

In the social study by Ergün et al, it was detected that $9.5 \%$ of the pregnant women knew about

Table 3. Answers of the pregnant women among the participants who heard about oral glucose tolerance test, double test, triple test or TORCH screening tests for not taking or wanting to $t$

\begin{tabular}{|c|c|c|}
\hline $\begin{array}{l}\text { Why didn't you take or didn't want to take OGTT (oral glucose tolerance) } \\
\text { test? }\end{array}$ & $\mathrm{n}$ & $\%$ \\
\hline May hurt my child & 33 & 28.44 \\
\hline Not stated & 29 & 25.0 \\
\hline I didn't find it necessary & 13 & 11.20 \\
\hline I'm a gestational diabetes patient & 7 & 6.03 \\
\hline My blood sugar follow-ups are normal & 7 & 6,03 \\
\hline I couldn't go & 6 & 5.17 \\
\hline I may be diabetic due to oral glucose tolerance test & 5 & 4.31 \\
\hline The doctor didn't recommend & 5 & 4.31 \\
\hline Prof.Dr. Canan Karatay doesn't recommend & 3 & 2.58 \\
\hline I have gastric intolerance & 3 & 2.58 \\
\hline My husband doesn't want & 2 & 1.72 \\
\hline I don't want to have a child & 2 & 1.72 \\
\hline \multicolumn{3}{|l|}{ Why didn't you take or didn't want to double screening test? } \\
\hline The test result won't effect my maternity decision & 70 & 47.3 \\
\hline Not stated & 25 & 16.9 \\
\hline I couldn't come & 15 & 10.2 \\
\hline I didn't find it necessary & 10 & 6.8 \\
\hline Not to have doubt & 7 & 4.7 \\
\hline My husband didn't want & 6 & 4.1 \\
\hline May hurt the child & 5 & 3.4 \\
\hline Other & 4 & 2.7 \\
\hline Elder family members didn't want & 3 & 2.0 \\
\hline The doctor didn't recommend & 3 & 2.0 \\
\hline \multicolumn{3}{|l|}{ Why didn't you take or didn't want to triple screening test? } \\
\hline The test result won't change my maternity decision & 24 & 34.3 \\
\hline Not stated & 20 & 28.6 \\
\hline I took double screening test & 6 & 8.6 \\
\hline I couldn't come & 5 & 7.1 \\
\hline Other & 4 & 5.7 \\
\hline My husband didn't want & 3 & 4.3 \\
\hline The doctor didn't recommend & 3 & 4.3 \\
\hline
\end{tabular}

East J Med Volume:23, Number:2, April-June/2018 rubella, $16.8 \%$ about toxoplasma, $2.8 \%$ about CMV and $1.6 \%$ about HSV (12). In our study, it was detected that $28.4 \%$ of the pregnant women heard about TORCH infections. In the social study by Ergün et al, it was detected that TORCH infection analysis was made in only $27.6 \%$ of the pregnant women (12). In our study, it was detected that TORCH infection analysis was made in $35.2 \%$ of the pregnant women and $25 \%$ didn't know whether this analysis was made or not. We think that the cause for the higher ratios in our study compared to the ratios in the study by 
Kusaslan Avci and Oner / Pregnancy and Screening Tests

May hurt the child

Why didn't you take or didn't want to take TORCH test?

$\begin{array}{lcc}\text { Not stated } & 32 & 76.2 \\ \text { I'll consider it } & 5 & 11.9 \\ \text { I didn't find it necessary } & 3 & 7.1 \\ \text { I couldn't come } & 1 & 2.4 \\ \text { I took it before } & 1 & 2.4\end{array}$

* $\mathrm{n}$ " is high since some participants select more than one option

Ergün et al is the routine check of TORCH infections in our hospital.

In the social study by Ergün et al, it was detected that $37.2 \%$ of the pregnant women knew about the double screening test (12). In the study by Y1lar Erkek et at on pregnant women, it was detected that $56.3 \%$ knew about double screening test (13). In our study, it was detected that $76 \%$ of the pregnant women heard about double screening test. The cause for higher ratios in our study compared to the ratios of Yilar Erkek et al was due to asking the participants whether they heard about double screening test or not.

In the study by Coşkuner Potur et al on pregnant women, it was detected that triple screening test was made on $48.6 \%$ of pregnant women (14). In the social study by Ergün et al, it was detected that $40.8 \%$ of the pregnant women had triple screening test (12). In our study, it was detected that $16.3 \%$ of the pregnant women took triple screening test and $18.3 \%$ will take it. The cause for the low ratios in our study was related to the high ratio of the idea that the test result won't change the delivery decision and the low education level among the participants.

Current data reported that many pregnancy complications can be lowered due to GDM screening and treatment and perinatal results can be improved (15). In the study by Ergün et al, it was stated that $64.4 \%$ of the pregnant women knew about OGT'T (12). In our study, it was detected that $44.3 \%$ of the pregnant women knew about why OGTT is made. In the study by Ergün et al, it was detected that $51.2 \%$ of the pregnant women thought that OGTT should be done in pregnancy (12). In our study, it was detected that $52.8 \%$ of the pregnant women thought that OGTT should be done. Our ratios were found in line with the ratios by Ergün et al. In the study by Coşkuner Potur et al on pregnant women, it was detected that $70.3 \%$ of the pregnant women had OGTT (14). In our study, it was detected that $25 \%$ of the pregnant females had OGTT and 25\% will have it.
We couldn't compare these data as we couldn't find other studies we can compare our data on why pregnant women don't take OGTT, double screening, triple screening test and TORCH tests. We think that more advanced researchers are needed on these subjects.

\section{Conclusion}

In our study, it was observed that the knowledge levels of the pregnant women on screening tests and their ratio of taking screening tests were not satisfactory. It was detected that some of the pregnant women had wrong information on screening tests. Especially with in-service trainings, the sensitivity of especially the primary care employees should be increased for informing women between the ages of 15 and 49 on the screening tests made during pregnancy. The knowledge levels of women on screening tests made during pregnancy should be increased through seminaries, brochures and television programs for the females in fertility age. A standard training should be programmed to inform pregnant women on the screening tests made during pregnancy and this training should be managed in Family Health Centers and hospitals.

Source of Funding: The funding sources played no role whatsoever in design, planning, conducting, analyzing and interpreting the results, nor in the final draft and presentation of the data.

Knowledge: This article was produced from the expertise thesis entitled 'Examination of the Knowledge, Attitude and Behaviours of Pregnant Women on Screening Tests made during Pregnancy' conducted by Dr.Ercan Oner under the consultancy of Assist. Prof. Dr. Dilek Kusaslan Avci.

\section{References}

1. Madazlı R. Rh Uyuşmazlığı-Fetal Anemi Tedavisi.Herkes İçin Transfüzyon Tibb1 Sempozyum Dizisi 2005; 44: 263-264. 
2. Bolat F, Uslu S, Bülbül A, Cömert S, Güran Ö,Baş E, Nuhoğlu A. Yenidoğan indirekt hiperbilirubinemisinde ABO ve Rh uygunsuzluğunun karşılaştırılması.Ş.E.A.H.Tıp bülteni 2010; 44: 156-161.

3. Duran B, Toktamış A, Erdan Ö, Demirel Y, Mamik BA, Çetin M. Doğum Öncesi Bakımda Tartışmalı Bir Konu: TORCH Taraması. Cumhuriyet Üniversitesi Tip Fakültesi Dergisi 2002; 24: 185-190.

4. Lembet A. Erken gebelik döneminde genetik bozuklukların saptanması. In: Beksaç M,Demir N, Koç A, Yüksel A, editors. Maternal Fetal Tip \& Perinatoloji 2001; 232-242.

5. Yarabaş K, Ilgıı Ruhi H. Prenatal Tan1.Türkiye Klinikleri J Med Sci 2006; 26; 666-674.

6. Karakurt F, Çarlıoğlu A, Kasapoğlu B, Gümüş I. Gestasyonel Diyabetes Mellitus Tan1 ve Tedavisi. Yeni Tip Dergisi 2009; 26: 134-138.

7. Baydur Şahin S, Ayaz T, İlkkılıç K, Sezgin H, Mete Ural Ü. Gestasyonel Diyabette İnsülin Tedavi Gereksinimini Arttıran Risk Faktörleri. Firat Tip Dergisi 2014; 19: 193-196.

8. Şilfeler DB, Karateke A, Kuyucu E, Artunç B, Taşapınar B. Yirmidört Yaş ve Altı Gebelere Glukoz Tarama Testi Yapilmalı midir? Kartal Eğitim ve Araştırma Hastanesi Tip Dergisi 2010; 21: 117-121.
9. Şen C, Yayla M. Gebelikte İzlem ve Doğum. Türk Perinatoloji Derneği yayıni 2006; 1: 1.

10. Berkman S, Has R. Doğum Bilgileri. Düşük Riskli Gebelerde Antenatal Tarama Testleri. Nobel Tip Kitapevleri 2004; 29-23.

11. Canbaz S, Sünter AT, Süren C, Pekşan Y. Kadın Sağlık Çalışanlarının Doğurganlık Özellikleri, Gebelik ve Doğum Sonu Dönemdeki Çalışma Koşulları. Kocatepe Dergisi 2005; 6: 39-44.

12. Ergün P, Köken GN, Coşar E, Şahin FK, Tolga Arı̈̈z D, Yılmazer M. Gebelerin üçlü tarama testi ve gebelikte yapılan diğer testler hakkındaki bilgi düzeyinin ölçülmesi.Koruyucu hekimlik bülteni 2011; 10: 403-408.

13. Yılar Erkek Z, Koçoğlu FM. Tokat il merkezinde çalışan ebelerin üçlü tarama testine ilişkin bilgi uygulama düzeylerinin saptanmas1.Gümüşhane Üniversitesi Sağl1k Bilimleri Dergisi 2016; 5: 16-22.

14. Coşkuner Potur D, Yiğit F, Çıtak Bilgin N. Anne adaylarının fetal sağlığ1 değerlendiren testlere yaklaşımının kalitatif incelenmesi. Maltepe Üniversitesi Hemşirelik Bilim ve Sanat1 Dergisi 2009; 2: 3.

15. Kumru S. Gebelik Diyabetinde Tarama ve Tan1 Testleri.Güncel Durum Perinatoloji Dergisi 2014; 22: 42-52. 